\title{
The concept of representative elementary length (REL) as an effective tool to study scale effects in rock engineering problems
}

\author{
Davide Elmo(1) and Doug Stead ${ }^{(2)}$ \\ (1) NBK Institute of Mining Engineering, University of British Columbia, Vancouver, Canada. \\ (2) Department of Earth Sciences, Simon Fraser University, Vancouver, Canada. \\ delmo@mining.ubc.ca
}

\begin{abstract}
In this paper, a discrete fracture network approach (DFN) is used to study scale effects on rock quality designation (ROD) measurements. ROD is a parameter that describes rock mass quality and represents a fundamental component of several rock mass classification systems. The results demonstrate that it is possible to define a representative elementary length (REL), above which ROD measurements represent an average indicator of rock mass quality. However, the directional bias of ROD measurements is such that the choice of REL is itself a function of the orientation of the sampling line used to estimate RQD. By considering multiple sampling directions, this paper introduces the concept of a REL Ellipsoid, whereby the normalized value of the REL along three sampling directions indicates the degree of homogeneity and isotropy of the rock mass with increase in problem scale. In the authors' opinion, the REL Ellipsoid concept allows to better capture the nature of the 3D representative elementary volume (REV) for both isotropic and anisotropic rock masses Mapping data from a room-and-pillar mine are used in the initial validation of the proposed REL Ellipsoid concept.
\end{abstract}

Keywords: Discrete fracture network approach (DFN), rock quality designation (RQD), rock mass classification systems, representative elementary length (REL), REL Ellipsoid concept.

\section{El concepto de longitude elemental representativa (REL) como una herramienta eficiente para estudiar los efectos de escala en problemas de ingeniería de rocas}

\begin{abstract}
RESUMEN
En este trabajo se utiliza una metodología de red de fracturas discretas (DFN) para estudiar los efectos de escala sobre las medidas de designación de calidad de la roca $(R Q D)$. $R Q D$ es un parámetro que describe la calidad del macizo rocoso y representa un componente fundamental de varios sistemas de clasificación de los macizos rocosos. Los resultados demuestran que es posible definir una longitud elemental representativa (REL) por encima de la cual las medidas de ROD representan un indicador medio de la calidad del macizo rocoso. No obstante, el sesgo direccional de las medidas de ROB es tal que la elección de la REL es, ella misma, una función de la orientación de la línea de muestreo utilizada para estimar el ROD. Mediante la consideración de múltiples direcciones de muestreo, este trabajo introduce el concepto del Elipsoide REL, por lo cual el valor normalizado del REL a lo largo de tres direcciones de muestreo indica el grado de homogeneidad e isotropía del macizo rocoso con incremento en el problema de escala. En opinión de los autores, el concepto de Elipsoide REL permite capturar mejor la naturaleza del volumen elemental representativo (REV) tridimensional tanto para masas rocosas isótropas como anisótropas. La cartografía de datos de un mina, de tipo salas y pilares, se ha utilizado en una validación inicial del concepto de Elipsoide REL propuesto.
\end{abstract}

Palabras clave: metodología de red de fracturas discretas (DFN), designación de calidad de la roca (RDQ), sistemas de clasificación de los macizos rocosos, longitud elemental representativa (REL), concepto de Elipsoide REL 


\section{Introduction}

The inhomogeneous and discontinuous nature of rock masses, both at the macroscopic and microscopic scale, is such that rock mechanics tests and the derived rock mechanics parameters are a function of the dimensions of the sampling volume. The types of scale effect can be considered in two categories (Cundall, 2008): i) microscale, due to the randomly distributed flaws in an otherwise intact rock specimen; and ii) macroscale, due to natural fratures related to systematic jointing patterns. The focus of this paper is the latter, macroscale effects. The mechanical response of a fractured rock mass is non-uniform due to the orientation, spacing and persistence of the discontinuities (Pine \& Harrison, 2003). Adapting the original definition of a REV by Hill (1963) to rock engineering problems, the REV is the smallest rock mass volume for which the mechanical properties would be representative of the whole. The REV would correspond to a sampling region in which rock mass parameters (orientation, spacing and persistence) no longer influence rock mass behavior, and the REV region can therefore be considered homogeneous and isotropic, Figure 1. The REV can be defined for various physical parameters. Bear (2013) defined the REV using the concept of porosity in rock masses according to the theory of porous media; when applied to numerical analysis, the concept of REV defines the scale above which a problem may be treated as an equivalent continuum (e.g. Esmaieli et al., 2010; Zhang et al., 2012; Elmo, 2012).

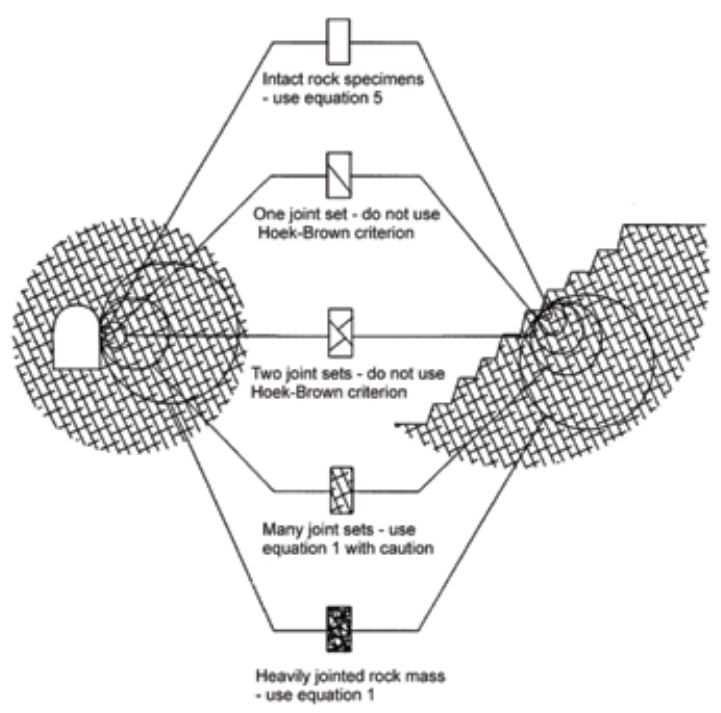

Figure 1. Diagram showing the transition from intact to a heavily jointed rock mass with increasing sample size (Hoek, 2007).

Figura 1. El diagrama muestra la transición desde una roca intacta hasta una roca fuertemente fracturada con con un incremento del tamaño de la muestra (Hoek, 2007).
Rock mass classification systems such as the rock mass rating system (RMR; Bieniawski 1989), Q-index (Barton et al. 1974) and the geological strength index (GSI; Hoek et al., 1995, 2019) provides a quantitative measure to compare geological conditions at different sites (Elmo and Stead, 2010). ROD represents a fundamental parameter in several rock mass classification systems, including RMR, and $\mathrm{Q}$ index. Hoek et al. (2013) proposed a quantification of GSI that incorporates ROD. Despite the widespread use of classification systems in geotechnical and rock engineering, there is no clear method to upscale classification ratings to consider scale effects. Whereas the work by Cai et al. (2004) indirectly attempts to provide a scale quantification of GSI, the method does not truly account for scale effects, since in its initial conception the GSI table was defined for a problem size not exceeding the typical dimensions of a road tunnel (10 m scale). Integrating a discrete fracture network (DFN) approach with geomechanical modelling of rock mass failure, Elmo et al. (2018) have demonstrated that GSI does decrease as the sampling region approaches the REV (Figure 2).

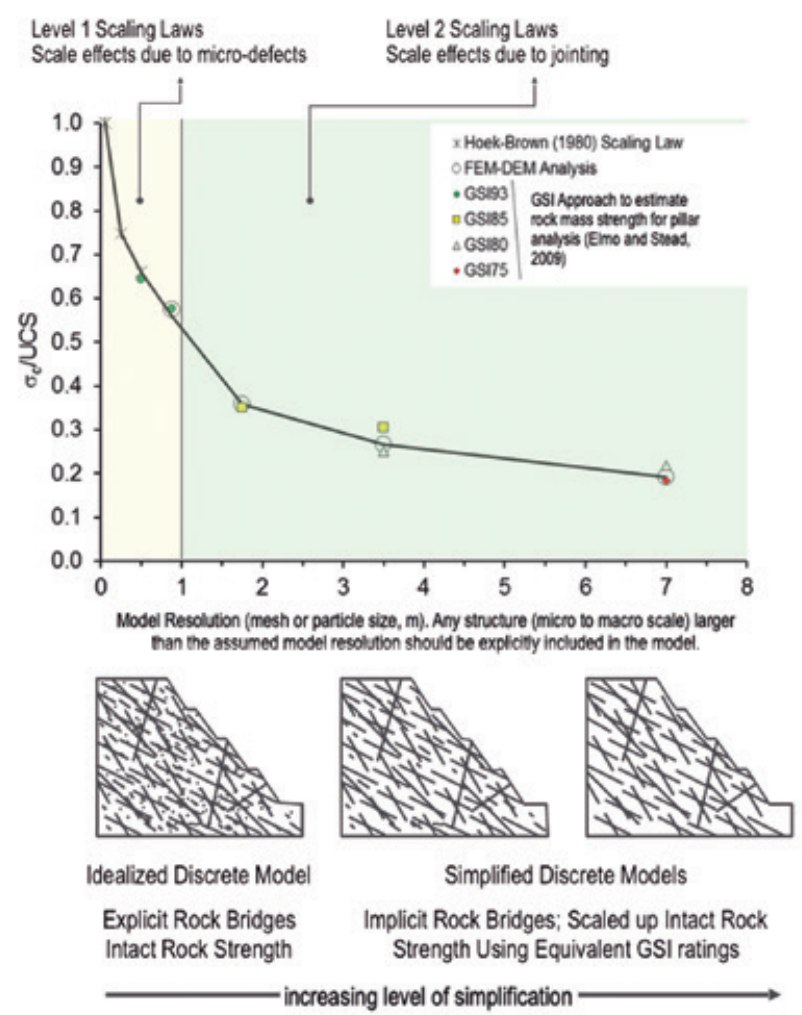

Figure 2. Level of scale effects and correlation with GSI (modified from Elmo et al., 2018).

Figura 2. Nivel de los efectos de escala y correlación con GSI (modificado de Elmo et al., 2018). 
In this paper the authors present a study of the scale effects on RQD measurements and introduce the concept of a REL, representative elementary length above which ROD measurements represent an average indicator of rock mass quality. The definition of the REL is further developed into a REL Ellipsoid concept, whereby the normalized value of REL along three sampling directions would mitigate the directional bias of both ROD and REL. The proposed REL Ellipsoid concept could be used to indicate the degree of homogeneity and isotropy of the rock mass with increase in e problem scale.

\section{RQD and DFN-based analysis of scale effects}

$R O D$ is defined as the cumulative length of intact core pieces longer than $10 \mathrm{~cm}$ (threshold length, $\tau$ ) as a percentage of the total length of core, or interval length $L$, (Deere et al., 1967). The widespread use of ROD in rock engineering is largely due to the simplicity in its definition; however, RQD is known to have several limitations, including:

i. ROD is sensitive to the relative orientation of the fractures with respect to the orientation of the borehole (or scanline);

ii. RQD is sensitive to the assumed $10 \mathrm{~cm}$ threshold and the correct choice of core logging interval; and

iii. ROD values may also depend on the experience of the engineer logging the core and the ability to distinguish between natural and mechanically induced fractures.

iv. ROD ignores the the effects that both incipient fractures and veins have on rock mass strength.

Of interest, early critics (Heuze, 1971) claimed that ROD was not "suited to form the basis for an engineering classification system of all rock masses, in terms of stability and support requirements". More recently, Pells et al. (2017) have questioned the use of RQD, arguing that its incorporation into rock mass classification systems is no longer necessary. The objective of this paper is not to further criticise the use of ROD as a rock mass classification tool; rather, the authors suggest using ROD's known limitations to improve on the original definition of the representative elementary volume (REV) applied to rock materials.

Using a discrete fracture network (DFN) approach Wang et al. (2017) demonstrated that ROD would converge to a constant "average" value for $L>10 \mathrm{~m}$. However, the same study has revealed that ROD values calculated along short interval lengths $(L<3 \mathrm{~m})$ may vary significantly, even for a homogeneous rock mass (assuming a rock mass volume of $30 \mathrm{~m}^{3}$ ), and upper and lower bound scaling curves could be defined that converge to an average ROD as $L$ increases. Other authors have suggested that ROD would increase with increasing study size (Zhang et al., 2013). These apparently contrasting results are easily explained by considering that in their paper Zhang et al. (2013) calculated ROD using threshold lengths $t$ larger than $1 \mathrm{~m}$ (not commonly used in rock engineering problems), and a DFN model in which the maximum linear fracture frequency $\left(P_{10}\right.$, number of fractures per unit length) was 0.6 , which would suggest that either the study site was a massive rock mass or the intensity in the DFN model was not corrected to account for truncation bias (minimum trace length below which fractures are not mapped in the field).

Zhang et al. (2013) stated that the threshold length $t$ should be chosen in relation to the fracture spacing (defined by the symbol $\lambda$ ). Whereas this statement is generally true, the term spacing is generally reserved to denote the normal distance between fractures with similar orientations. Accordingly, the statement above should be corrected to include 1D (linear) fracture frequency. For commonality with the DFN convention (Dershowitz and Herda, 1992), in this paper the term $\mathrm{P}_{10}$ is adopted in lieu of $\lambda$ to denote fracture frequency or number of fractures per unit length. For a constant spacing $\mathrm{P}_{10}$, and $t<\mathrm{P}_{10}$, then ROD would be equal to 100 irrespective of the assumed interval length; for a constant $\mathrm{P}_{10}$ and $t>\mathrm{P}_{10}$ then RQD values would be 0 . In this analysis the standard threshold length $t$ of 10 $\mathrm{cm}$ is adopted to calculate RQD, and a stochastic approach used such that for constant $P_{10}$ the actual location of the fractures along the sampling line would correspond to a Poisson process resulting in an exponential distribution of fracture spacing.

The generated DFN model (Figure 3 ) is representative of the natural joining encountered in a now disused room-and-pillar mine in Derbyshire (U.K.). Details about the mapping approach, data analysis and generation of the DFN model are given in Elmo (2006) and Wang et al. (2017). Three additional DFN models were generated by increasing the volumetric fracture frequency $\left(\mathrm{P}_{32}\right)$ while keeping all other parameters constant. Three $30 \mathrm{~m}$ long artificial boreholes (one vertical, $Z$, one horizontal in-plane, $X$, and one horizontal out-of-plane, $Y$ ) were used in the model to determine ROD for varying length intervals $(3 \mathrm{~m}, 5 \mathrm{~m}$, and $10 \mathrm{~m}$, and $30 \mathrm{~m}$ ). The results are summarised in Tables 1 to 3 for the $Z, X$, and $Y$ boreholes, respectively. The results are presented in terms of minimum and maximum ROD calculated along the specified intervals ( 3 $\mathrm{m}, 5 \mathrm{~m}$, and $10 \mathrm{~m}$, and $30 \mathrm{~m}$ ). Over the full length of the boreholes there are 10 measurements for $3 \mathrm{~m}$ long intervals (i.e. ratio of 30 to 3 ), 6 measurements for $5 \mathrm{~m}$ long intervals, 3 measurements for $10 \mathrm{~m}$ long 
intervals, and only 1 measurement for a $30 \mathrm{~m}$ long interval.

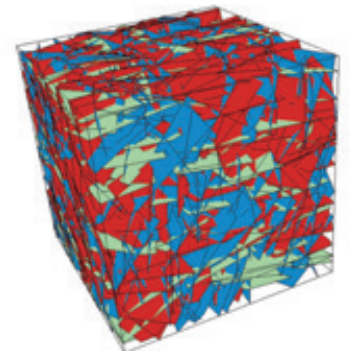

(a)

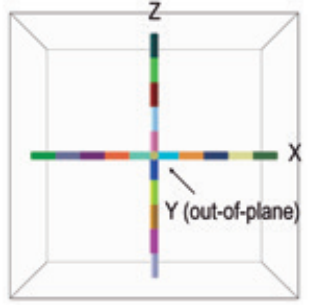

(b)
Synthetic DFN model of a $30 \mathrm{~m}^{3}$ rock mass

Orthogonal boreholes and intervals used to calculate fracture frequency and RQD

Figure 3. Synthetic homogeneous rock mass generated using a DFN approach and representative of the natural jointing encountered in a now disused room-and-pillar mine.

Figura 3. Masa rocosa simulada utilizando el enfoque DFN y representativa de la fracturación natural que se encuentra en una mina de tipo salas y pilares.

Core logging is typically performed by measuring fractures along relatively short intervals $(1.5 \mathrm{~m})$. Whereas such a limited core length may be useful to identify poor quality zones, it is argued that it cannot be representative of the rock mass as whole; indeed, Palmstrom (2001, 2005) recommended to choose run lengths according to geological and structural domains. As shown in Figure 4 and Figure 5, relatively large variations of ROD are observed for shorter interval length $L(L<3$ $\mathrm{m})$, and as $L$ increases, the calculated ROD approach a constant average value. However, Figure 6 shows that the definition of representative elementary length (REL, 1D analogue to REV) would not be unique:

i. REL would need to be defined with respect to a small rate of ROD variation (e.g. $2 \%$ );

ii. REL would be a function of the rock mass's volumetric fracture intensity;

iii. REL would be directionally dependent; and

iv. REL would need to consider changes in structural domains along the borehole (i.e. REL should be defined for each domain).

Vertical borehole, $\mathrm{Z}$

\begin{tabular}{|c|c|c|c|c|c|c|c|c|}
\hline & \multicolumn{2}{|c|}{ RQD 30 m (1 interval) } & \multicolumn{2}{|c|}{ RQD $10 \mathrm{~m}$ (3 intervals) } & \multicolumn{2}{|c|}{ RQD 5 m (6 intervals) } & \multicolumn{2}{c|}{ RQD $3 \mathrm{~m}$ (10 intervals) } \\
\hline $\mathrm{P}_{32}\left(\mathrm{~m}^{2} / \mathrm{m}^{3}\right)$ & Minimum & Maximum & Minimum & Maximum & Minimum & Maximum & Minimum & Maximum \\
\hline 3 & 95 & 95 & 92 & 97 & 90 & 99 & 87 & 99 \\
\hline 5 & 83 & 83 & 78 & 85 & 75 & 90 & 72 & 90 \\
\hline 7 & 76 & 76 & 70 & 81 & 69 & 83 & 63 & 87 \\
\hline 10 & 57 & 57 & 54 & 63 & 51 & 70 & 41 \\
\hline
\end{tabular}

Table 1. Vertical borehole Z- minimum and maximum ROD calculated along the specified intervals.

Tabla1. Sondeo vertical $Z, R Q D$ mínimo y máximo, calculado a lo largo de intervalos especificados.

Horizontal borehole, $\mathrm{X}$

\begin{tabular}{|c|c|c|c|c|c|c|c|c|}
\hline & RQD $30 \mathrm{~m}$ (1 interval) & \multicolumn{2}{|c|}{ RQD $10 \mathrm{~m}$ (3 intervals) } & \multicolumn{2}{|c|}{ RQD $5 \mathrm{~m}$ (6 intervals) } & \multicolumn{2}{c|}{ RQD $3 \mathrm{~m}$ (10 intervals) } \\
\hline $\mathrm{P}_{32}\left(\mathrm{~m}^{2} / \mathrm{m}^{3}\right)$ & Minimum & Maximum & Minimum & Maximum & Minimum & Maximum & Minimum & Maximum \\
\hline 3 & 88 & 88 & 86 & 90 & 81 & 90 & 78 & 92 \\
\hline 5 & 71 & 71 & 66 & 78 & 62 & 84 & 60 & 85 \\
\hline 7 & 58 & 58 & 48 & 66 & 45 & 72 & 38 & 74 \\
\hline 10 & 38 & 38 & 34 & 42 & 30 & 51 & 30 & 57 \\
\hline
\end{tabular}

Table 2. Horizontal borehole $X$ - minimum and maximum ROD calculated along the specified intervals.

Tabla 2. Sondeo horizontal $Z, R Q D$ mínimo y máximo, calculado a lo largo de intervalos especificados.

\section{Horizontal borehole, $\mathrm{Y}$}

\begin{tabular}{|c|c|c|c|c|c|c|c|c|}
\hline & RQD 30 $\mathrm{m}$ (1 interval) & \multicolumn{2}{|c|}{ RQD $10 \mathrm{~m}$} & (3 intervals) & \multicolumn{2}{|c|}{ RQD 5 m (6 intervals) } & \multicolumn{2}{c|}{ RQD 3 m (10 intervals) } \\
\hline $\mathrm{P}_{32}\left(\mathrm{~m}^{2} / \mathrm{m}^{3}\right)$ & Minimum & Maximum & Minimum & Maximum & Minimum & Maximum & Minimum & Maximum \\
\hline 3 & 93 & 93 & 91 & 95 & 89 & 98 & 85 & 100 \\
\hline 5 & 85 & 85 & 80 & 88 & 71 & 92 & 68 & 94 \\
\hline 7 & 73 & 73 & 67 & 80 & 59 & 85 & 49 & 85 \\
\hline 10 & 65 & 65 & 61 & 69 & 53 & 74 & 46 & 75 \\
\hline
\end{tabular}

Table 3. Horizontal boreholeY - minimum and maximum ROD calculated along the specified intervals.

Tabla 3. Sondeo horizontal $Y, R Q D$ mínimo y máximo, calculado a lo largo de intervalos especificados. 

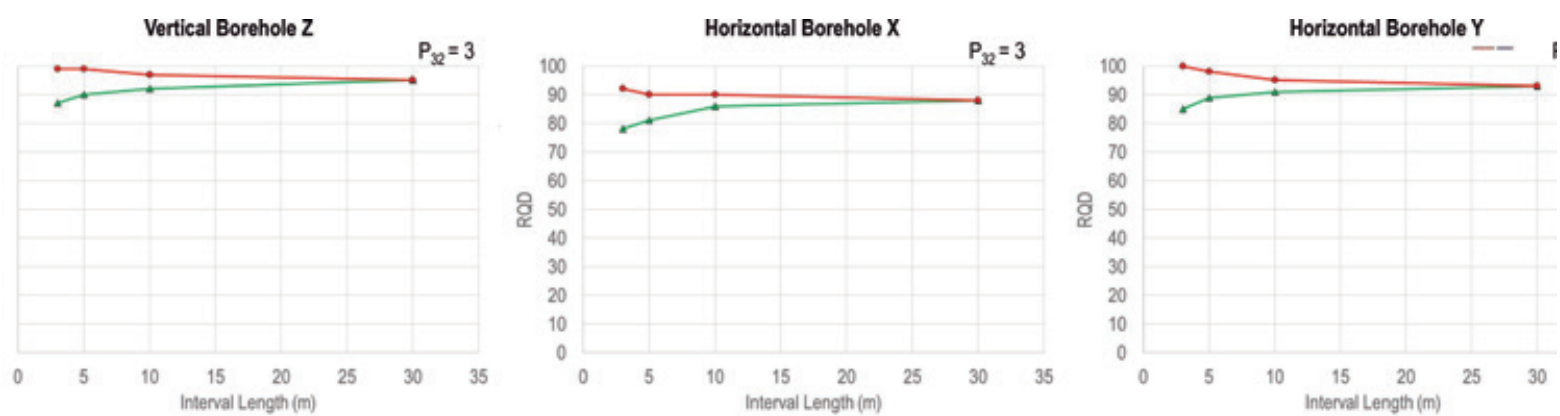

$\rightarrow-R Q O M n \rightarrow R Q D$ Max

$$
\rightarrow \text { RQD Min } \rightarrow \text { ROO Max }
$$

$\rightarrow$ RQD Min $\rightarrow$ RQD Max
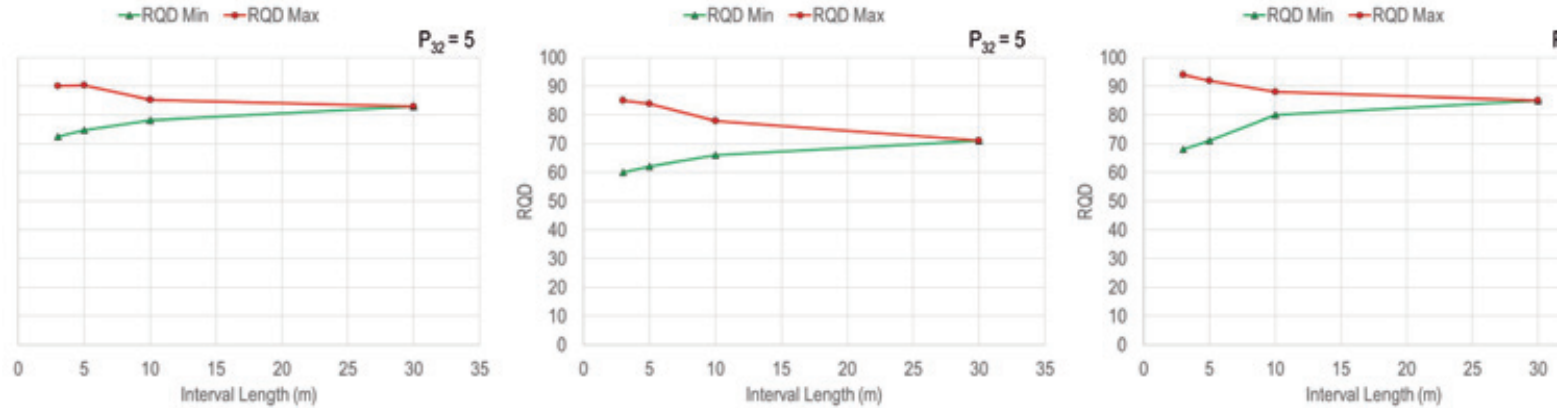

Figure 4. Minimum and maximum RQD for boreholes $Z, X$, and $Y$ calculated along the specified interval lengths (P32 intensities of 3 and 5 $\mathrm{m}^{2} / \mathrm{m}^{3}$ respectively).

Figura 4. $R Q D$ mínimo y máximo a lo largo de sondeos $Z, X$ e $Y$, calculado a lo largo de intervalos especificados (intensidades $P 32$ de 3 y $5 \mathrm{~m}^{2} / \mathrm{m}^{3}$ respectivamente).
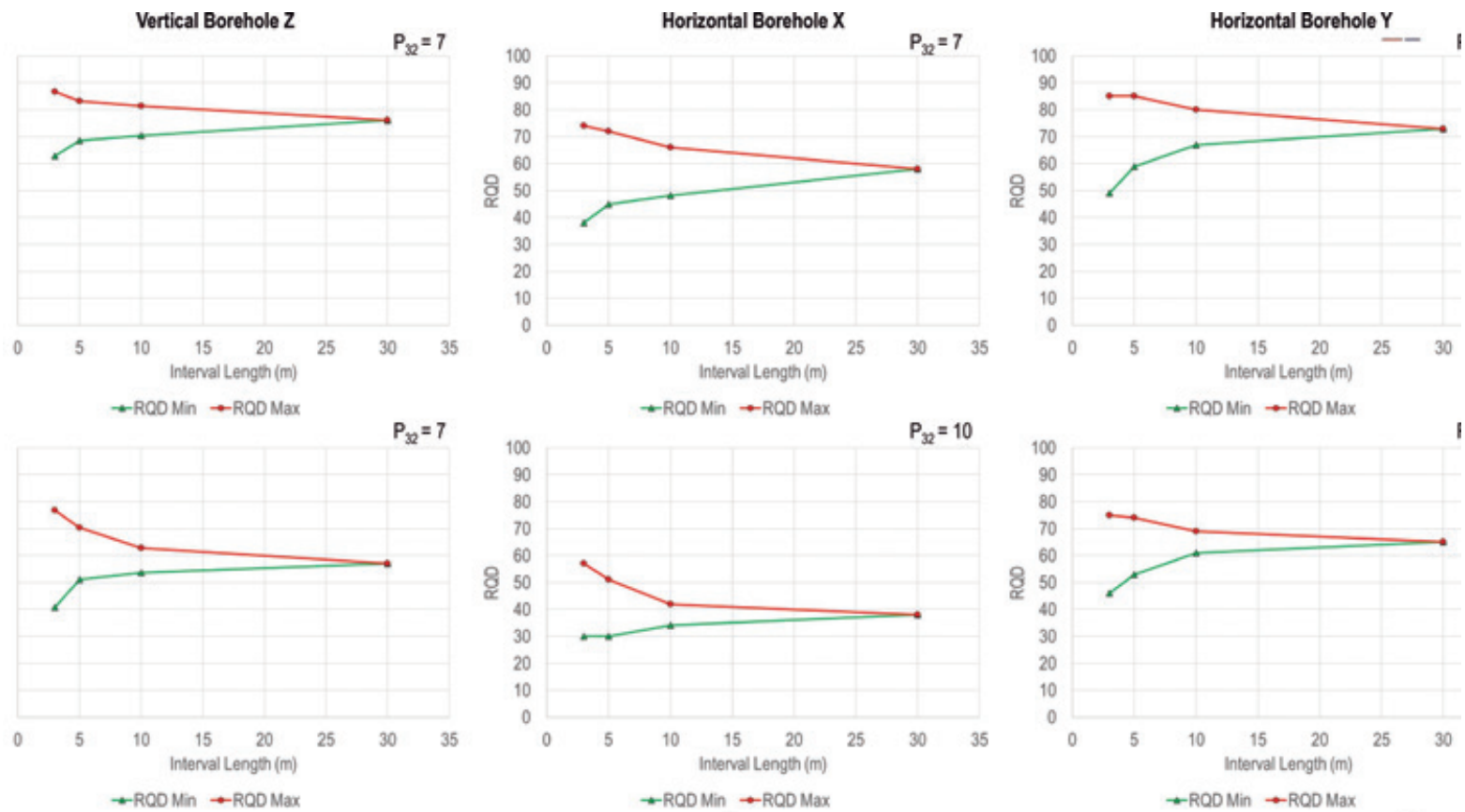

Figure 5. Minimum and maximum RQD for boreholes $Z, X$, and $Y$ calculated along the specified interval lengths (P32 intensities of 7 and 10 $\mathrm{m}^{2} / \mathrm{m}^{3}$ respectively).

Figura 5. RQD mínimo y máximo a lo largo de sondeos $Z, X$ e $Y$, calculado a lo largo de intervalos especificados (intensidades $P 32$ de 7 y $10 \mathrm{~m}^{2} / \mathrm{m}^{3}$ respectivamente). 
The directional bias of REL provides the opportunity to reflect on the limitations of the original definition of REV applied to rock materials. Historically, the definition of REV applies to composite material such as reinforced concrete. However, a rock mass cannot truly be considered a composite material due to the presence of natural discontinuities. The definition of REV assumes that it would be possible to simulate the behaviour of a fractured rock mass at a scale larger or equal to the REV using an equivalent continuum approach, whereby in the continuum model an heterogenous rock mass is represented by a homogeneous media with equivalent mechanical properties. The REV should therefore be large enough for the rock mass to be considered isotropic. In this context, the estimation of the REL along different sampling lines would allow to identify, for a given volumetric fracture intensity, whether a REV exists above which representative and isotropic rock mechanical properties can be defined.

REL can therefore become a useful scale effect index, that relate scale effects to the degree of anisotropy for the rock mass. For this purpose, the normalised $R E L_{n}$ values measured for three mutually orthogonal sampling lines $\left(\mathrm{REL}_{\mathrm{n}, \mathrm{x}} ; \mathrm{REL}_{\mathrm{n}, \mathrm{y}}\right.$ and $\mathrm{REL}_{\mathrm{n}, \mathrm{z}}$ ) would form the semi-axes of an ellipsoid, termed a REL Ellipsoid, Figure 7. For isotropic rock masses, it would be reasonable to expect that $R E L_{n, x}=R E L_{n, y}=R E L_{n, z}=1$ and the REL Ellipsoid to converge to a sphere, in which case the scale of the REL could be considered the REV of the rock mass. The larger the differences between $R E L_{n}$ value, the larger the degree of anisotropy of the rock mass, in which case the volume of the ellipsoid
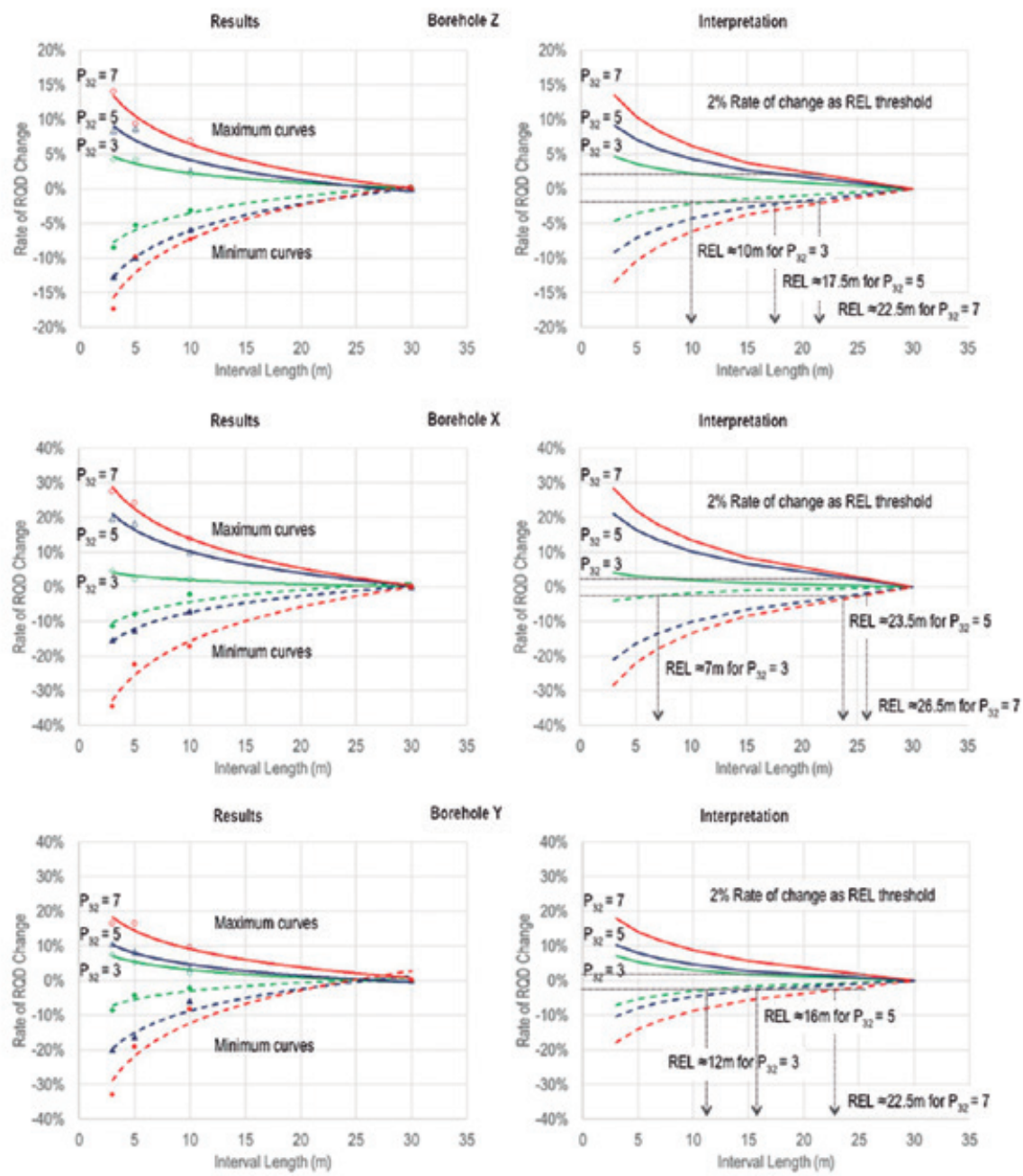

Figure 6. Determination of REL for the three mutually orthogonal boreholes.

Figura 6. Determinación de REL para los tres sondeos mutuamente ortogonales. 

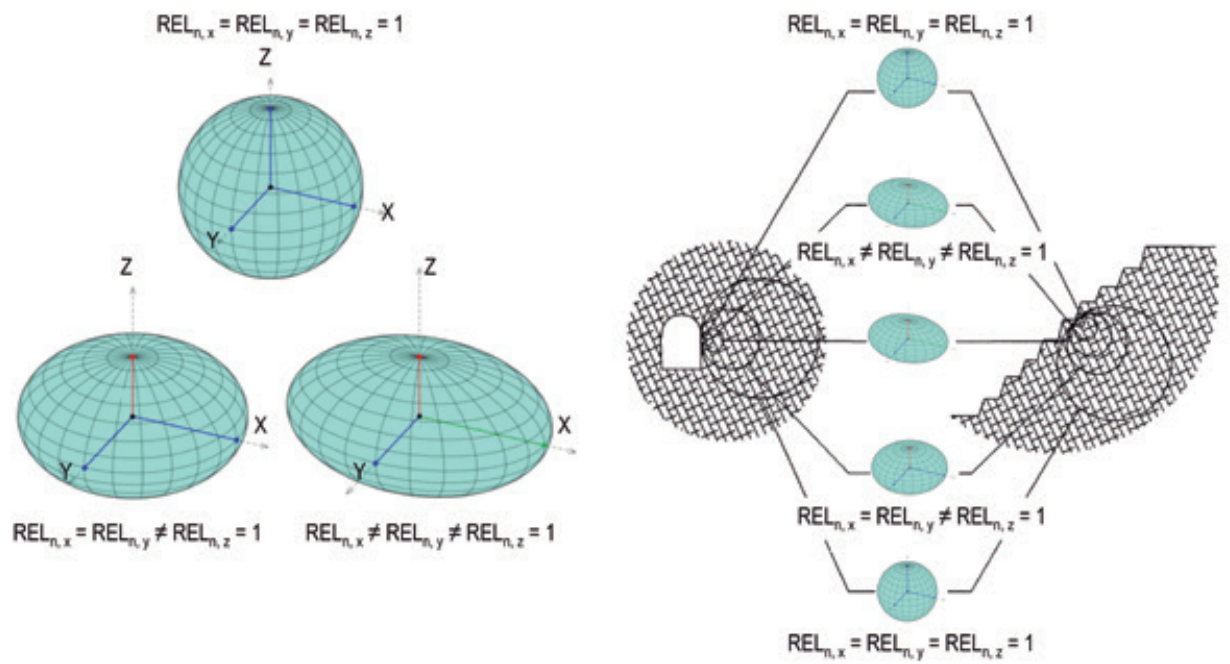

Figure 7. (a) Concept of REL Ellipsoid and (b) transition from intact to a heavily jointed rock mass with increasing sample size could be re-interpreted using the REL Ellipsoid concept (sphere and ellipsoid graphics modified from https://commons.wikimedia.org/w/index.php?curid=45585493).

Figura 7. (a) Concepto de Elipsoide REL y (b) transición desde macizo rocoso intacto hasta fuertemente fracturado con incremento del tamaño de la muestra y que se podría reinterpretar utilizando el concepto de Elipsoide REL (gráficos de esferas y elipsoides modificados de https://commons.wikimedia.org/w/index.php?curid=45585493).

would represent a non-homogenous REV that could not be analysed using simple continuum methods. It would also be possible to size the REL Ellipsoid to a function of the rock mass volumetric intensity. In this context, the transition from intact to a heavily jointed rock mass with increasing sample size could be re-interpreted using the REL Ellipsoid concept, Figure 8. The REL ellipsoid concept has similarities with the damage ellipsoid model introduced by Havaej and Stead (2016), which looks at cracking in three directions. Increasing damage could lead to a transition from a strong directionally dependent prolate ellipsoid to a sphere. This would result in a modified GSI rating as described by Cai et al (2004). However, there may be the case where different ellipsoids would simply represent different structural domains. In this context, Figure 8 assumes the existence of only one structural domain, i.e. scale dependency cannot be extrapolated across domains.

\section{Conclusions}

The results show that the process of rock mass classification through ROD, or through any classification systems which uses ROD, has to recognize the existence of scale effects and their implications for rock engineering design when using classification ratings calculated for different problems scales. With several researchers now questioning the use of ROD in rock classification systems, the authors suggest that ROD could find a new application as a tool to capture rock mass scale effects. Synthetic rock masses generated using a DFN approach allow for the characterization of rock mass variability in terms of ROD and rock mass quality. In this paper, the influence of interval length $L$ on the estimated ROD value was used to define a representative elementary length, REL. When considering REL estimated along different sampling lines, it is then possible to identify, for a given volumetric fracture intensity, whether a REV exists above which representative and isotropic rock mechanical properties can be defined. The concept of REL Ellipsoid is introduced to both define the scale at which the REL can be considered equivalent to the REV of the rock mass, and to identify whether the resulting REV truly represents a homogenous and isotropic media.

There is a need to extend the current work to consider DFN models with more complex fracture networks and to compare actual ROD measurements along boreholes to the simulated ROD values measured in the associated DFN models. It is expected that further work will also consider the relationship between the simulated ROD values (for different interval length) and rock mass fragmentation, and the relationship between rock mass scale and assumed threshold length $t$ used to calculated ROD. Note that the results of the current analysis do not include shear and fault zones; those should be treated in numerical models as deter- 
ministic features with specific thickness and material properties. It is also important to recognize that the discussion has so far been limited to open discontinuities. As discussed by Jakubec and Esterhuizen (2000), rock mass classification systems cannot include cemented joints and veinlets, since those are not included as part of the rock mass assessment, whether using $1 \mathrm{D}$ or $2 \mathrm{D}$ sampling.

\section{References}

Barton, N., Lien, R., Lunde, J. 1974. Engineering classification of rock masses for the design of tunnel support. In: Rock Mechanics, 6 (4), 189-236.

Bear, J., 2013. Dynamics of fluids in porous media. Courier Corporation.

Bieniawski ZT, 1989. Engineering rock mass classification. Wiley, New York, 251 pages.

Cai, M., Kaiser, P.K., Uno, H., Tasaka, Y. and Minami, M. 2004. Estimation of rock mass strength and deformation modulus of jointed hard rock masses using the GSI System. Int. J. Rock Mechanics and Mining Sciences, 41(1), pp. 3-19.

Cundall, P.A. 2008. Quantifying the size effect of rock mass strength. SHIRMS 2008. Australian Centre for Geomechanics, Perth.

Deere, D.U. and Hendron, A.J., J., Patton, FD, and Cording, EJ (1967). Design of surface and near-surface construction in rock. In Failure and Breakage of Rock, Eighth Symposium on Rock Mechanics (pp. 237-302).

Dershowitz, W.S., Herda, H.H. 1992. Interpretation of fracture spacing and intensity. In: Proceedings of the 33rd US Rock Mechanics Symposium, Publ. 33, 757-766.

Elmo, D., Donati, D., Stead, D. 2018. Challenges in the characterization of rock bridges. Submitted to Engineering Geology. doi.org/10.1016/j.enggeo.2018.06.014.

Elmo, D. and Stead, D., 2010. An integrated numerical modelling-discrete fracture network approach applied to the characterisation of rock mass strength of naturally fractured pillars. Rock Mechanics and Rock Engineering, 43(1), pp.3-19.

Elmo, D., 2006. Evaluation of a hybrid FEM/DEM approach for determination of rock mass strength using a combination of discontinuity mapping and fracture mechanics modelling, with particular emphasis on modelling of jointed pillars (Doctoral dissertation, University of Exeter).

Esmaieli, K., Hadjigeorgiou, J. and Grenon, M. 2010. Estimating geometrical and mechanical REV, based on synthetic rock mass models at Brunswick Mine. Int. J. Rock Mech. Min. Sci., 47(6), 915-926.

Havaej, M. and Stead, D. 2016. Investigating the role of kinematics and damage in the failure of rock slopes. Computers and Geotechnics, 78, 181-193.

Hill, R., 1963. Elastic properties of reinforced solids: some theoretical principles. J. Mech. Phys. Solids, 11, 357-372.

Hoek, E., 2007. Practical Rock Engineering. https://www. rocscience.com/learning/hoek-s-corner.

Hoek, E., Carter, T.G. and Diederichs, M.S., 2013. Quantification of the geological strength index chart. In 47th US Rock Mechanics/Geomechanics Symposium. American Rock Mechanics Association.

Hoek, E., Kaiser P.K. and Bawden W.F. 1995. Support of underground excavations in hard rock. Rotterdam, Balkema.

Hoek, E. and Brown, E.T. 2019. The Hoek-Brown failure criterion and GSI- 2018 edition. J. Rock Mech. Geotech. Eng. , In press, https://doi.org/10.1016/j.jrmge.2018.08.001

Jakubec, J. and Esterhuizen, G. 2000. Use of the mining rock mass rating (MRMR) classification: industry experience.

Palmstrom, A. 2001. In In-situ characterization of rocks. Sharma V.M. and Saxena K.R. eds. A.A. Balkema publishers, 2001, pp. 49-97.

Palmstrom, A. 2005. Underground Space Technology 20, 362-377

Pine RJ, Harrison JP (2003) Rock mass properties for engineering design. Q. J. Eng. Geol. Hydrogeol. 36, pp.5-16.

Pells, P.J., Bieniawski, Z.T., Hencher, S.R., Pells, S.E. 2017. Rock quality designation (ROD): time to rest in peace. Can. Geotech. J., 54, 825-834.

Wang, R., Elmo, D., Stead, D., Rogers, S. 2017. Characterisation of rock mass representative elementary volume using RQD and a discrete fracture network approach. In Proceedings of the 51st Int. Symp. Rock Mech., San Francisco, U.S. June 2017. Paper 760.

Zhang, W., Chen, J., Cao, Z., Wang, R. 2012. Size effect of RQD and generalized representative volume elements: $A$ case study on an underground excavation in Baihetan dam, Southwest China. Tunnelling and Underground Space Technology 35. pp. 89-98.

Recibido: julio 2019

Revisado: noviembre 2019

Aceptado: enero 2020

Publicado: marzo 2021 